\title{
IMPLEMENTASI ALGORITME TOPSIS UNTUK PEREKRUTAN KARYAWAN PADA PT. MITRA BUANA KOORPORINDO
}

\author{
Jarot Eko Prasetyo ${ }^{1)}$, Ady Widjaja ${ }^{2)}$ \\ ${ }^{1}$ Sistem Informasi, Fakultas Teknologi Informasi, Universitas Budi Luhur \\ ${ }^{1,2} \mathrm{Jl}$. Raya Ciledug, Petukangan Utara, Kebayoran Lama, Jakarta Selatan 12260 \\ E-mail : jarotekop@gmail.com ${ }^{1)}$, ady.widjaja@budiluhur.ac.id ${ }^{2)}$
}

\begin{abstract}
Abstrak
Sumber Daya Manusia yang berkualitas merupakan kunci kesuksesan dan keberhasilan sebuah badan usaha ataupun perusahaan. Untuk mendapatkan Sumber Daya Manusia yang berkualitas maka diperlukan proses seleksi calon karyawan yang benar-benar sesuai prosedur dan sesuai dengan kebutuhan perusahaan. Proses yang terjadi selama ini pada PT. Mitra Buana Koorporindo pada saat perekrutan karyawan dilakukan dengan mengecek satu persatu dokumen lamaran yang dikirimkan oleh para pelamar. Sehingga berdampak pada lamanya proses pengecekan berkas, juga adanya penilaian subyektif kepada para pelamar sehingga calon karyawan yang terpilih tidak memenuhi standar dari kebutuhan perusahaan. Hal ini mengakibatkan Sumber Daya Manusia menjadi tidak berkualitas. Pada penelitian ini menggunakan Algoritme TOPSIS dalam menghitung nilai dari masing-masing calon karyawan yang akan dipilih. Hasil dari penelitian ini adalah sebuah aplikasi sistem penunjang keputusan yang berbasis web dan menghasilkan bentuk keluaran berupa perangkingan dari masing-masing calon karyawan.
\end{abstract}

Kata kunci: pelamar, perusahaan, perekrutan

\section{PENDAHULUAN}

\subsection{Latar Belakang}

PT.Mitra Buana Koorporindo berdiri di Jakarta, 13 Februari 2007. Dengan karyawan lebih dari 180 orang. Mempunyai kantor pusat di Jakarta dengan menjangkau lebih dari 30 kota di seluruh wilayah nusantara. Fleksibel dalam hal persyaratan dan pengadaan termasuk sewa/leasing dan volume. Jenis usaha ini adalah penyedia solusi untuk infrastruktur IT. Menjalin kemitraan dengan sebagian besar vendor IT di Indonesia. Sumber Daya Manusia yang berkualitas merupakan kunci kesuksesan dan keberhasilan sebuah badan usaha ataupun perusahaan. Untuk mendapatkan Sumber Daya Manusia yang berkualitas maka diperlukan proses seleksi calon karyawan yang benar-benar sesuai prosedur dan sesuai dengan kebutuhan perusahaan. Proses yang terjadi selama ini pada PT. Mitra Buana Koorporindo pada saat perekrutan karyawan dilakukan dengan mengecek satu persatu dokumen lamaran yang dikirimkan oleh para pelamar. Sehingga berdampak pada lamanya proses pengecekan berkas, juga adanya penilaian subyektif kepada para pelamar sehingga calon karyawan yang terpilih tidak memenuhi standar dari kebutuhan perusahaan. Hal ini mengakibatkan Sumber Daya Manusia menjadi tidak berkualitas. sehingga kandidat yang terpilih bukanlah kandidat yang terbaik. Sehingga pada penelitian ini mengajukan sebuah algoritma TOPSIS yang diimplementasikan kedalam sebuah aplikasi, nilai dari masing-masing Alternatif akan dihitung dan dilakukan perangkingan melalui aplikasi. HR \& GA Dept. Head dapat melihat hasil perangkingan dan bisa memutuskan siapa yang berhak di rekrut menjadi karyawan pada PT.Mitra Buana Koorporindo.

\subsection{Batasan Masalah}

Ruang lingkup dalam penelitian ini mencakup antara lain:

a. Algortime atau Metode yang dipergunakan pada aplikasi sistem penunjang keputusan ini yaitu TOPSIS (Technique for Order of Preference by Similarity to Ideal Solution).

b. Kriteria yang dipergunakan dalam pengambilan keputusan diatur oleh pihak manajemen PT. Mitra Buana Koorporindo.

c. Laporan dibuat selama 1 tahun sekali / Setiap ada Permintaan Laporan.

\section{METODE PENELITIAN}

2.1. Metode dalam proses penelitian

Metode pada saat Penelitian dilaksanakan berguna untuk membuat kerangka kerja, adapun metode penelitian tersebut antara lain:

a. Mengidentifikasikan setiap permasalahan

Permasalahan-permasalahan yang terjadi pada saat penelitian dilakukan akan dirangkum dan dikumpulkan.

b. Studi Kepustakaan

Studi kepustakaan berguna dalam mencari bahan referensi terkait permasalahan yang terjadi pada saat penelitian. Studi kepustakaan bisa berupa jurnal ataupun buku yang membahas permasalahan tersebut. 
c. Penentuan Algoritme atau Metode dalam penyelesaian masalah.

Setelah membaca dan mempelajari studi kepustakaan yang diperoleh dari buku maupun jurnal-jurnal yang terkait dengan permasalahan dan referensi lainnya, maka diperoleh Algoritme atau metode untuk penyelesaian tersebut yaitu metode TOPSIS.

d. Tahap Desain dan pembuatan program.

Tahap ini adalah membuat bentuk tampilan layar pengguna supaya mudah dipahami dan dipelajari pengguna. Pada tahap ini juga program sudah berjalan dan dapat diimplementasikan. Adapun bahasa pemrograman yang digunakan adalah PHP.

e. Tahap Testing

tahap ini yaitu proses menguji seluruh fungsi dari masing-masing bagian program apakah sudah berjalan sesuai dengan keinginan dari pengguna serta menguji fungsi validitas dari program yang dibuat untuk menghindari bug pada program.

f. Proses Dokumentasi

Tahap ini adalah proses pendokumentasian seluruh penelitian yang telah dilakukan laporan seluruh dokumentasi akan diberikan kepada pimpinan untuk dikaji dan dievaluasi.

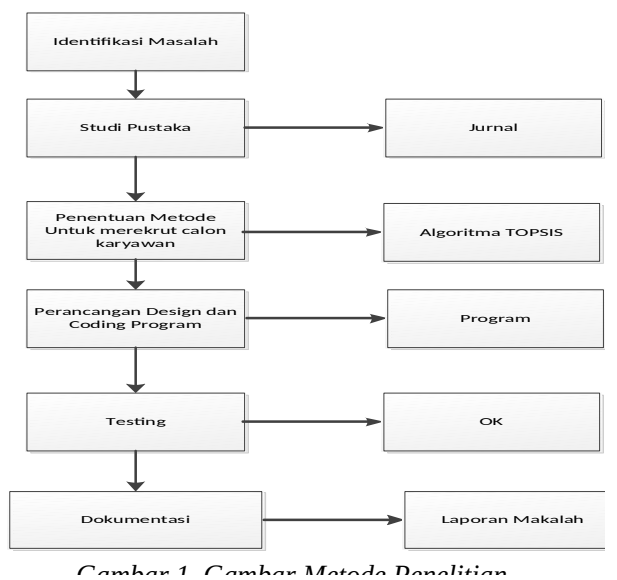

\subsection{Pengertian SPK}

Menurut ritongga, yudin (2014 : 19) Sistem pendukung keputusan atau SPK adalah sebuah bentuk sistem yang mampu mendukung seorang pimpinan dalam membuat sebuah keputusan.

\subsection{Fase Pengambilan Keputusan}

Menurut turban ada 4 Fase didalam mengambil sebuah keputusan yaitu :

a. Fase Intelligence yaitu tahap dalam mencari beberapa kriteria yang berguna untuk mengambil keputusan.

b. Fase Design yaitu tahap dalam menganalisis serta mempelajari permasalahan kemudian mengembangkannya menjadi sebuah pemodelan.

c. Fase Choice yaitu tahap dalam memilih sumber materi yang telah tersedia dan siap digunakan.

d. Fase implementasi yaitu tahap yang berfungsi untuk menjelaskan hasil daripenelitian yang telah dilakukan.

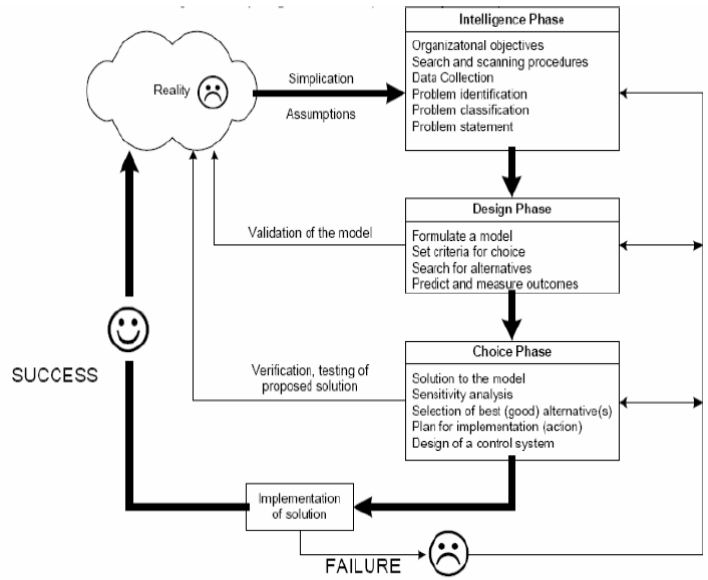

Gambar 2. Gambar Proses Pengambilan Keputusan (Turban, 2005)

\subsection{Langkah dalam Penyelesaian pada}

Metode Technique for Order Preferences by Similarity to an Ideal Solution (TOPSIS)

Adapun prosedur untuk melakukan perhitungan metode TOPSIS menurut Kusumadewi (2006) yaitu :

1) Menghitung nilai dari Matriks yang telah Ternormalisasi

Pada metode Topsis membutuhkan sebuah rating kinerja dari masing-masing kandidat calon karyawan.

Adapun Matriks yang ternormalisasi akan digambarkan pada persamaan 1 .

$$
r_{\mathrm{ij}}=\frac{x_{\mathrm{ij}}}{\sqrt{\sum_{\mathrm{i}=1}^{m}{X_{\mathrm{ij}}}^{2}}}
$$

2) Menghitung nilai matriks yang telah ternormalisasi dan terbobot

Pada persamaan 2 berfungsi untuk menunjukan tingkat kepentingan dari masing-masing alternatif berdasarkan kriteria ataupun subkriteria. Sedangkan pada persamaan 3 , berfungsi untuk menghitung nilai matriks yang telah dinormalisasi dan diberikan bobot penilaian.

$$
\begin{gathered}
\mathbf{W}=\left\{\mathbf{w}_{\mathbf{l}}, \mathbf{w}_{\mathbf{2}}, \mathrm{w}_{\mathbf{3}}, \ldots, \mathbf{w}_{\mathbf{n}}\right\} \\
\mathrm{y}_{\mathrm{ij}}=\mathrm{w}_{\mathrm{i}} \mathrm{r}_{\mathrm{ij}}
\end{gathered}
$$


3) Menghitung nilai sebuah Matriks Solusi Ideal Positif dan nilai Matriks Solusi Ideal Negatif. Nilai sebuah matriks Solusi ideal positif dan negatif diperoleh dari rating bobot yang telah dinorrmalisasi. Pada persamaan nomor 4 digunakan untuk menghitung nilai matrik solusi ideal positif dan negatif.

$$
\begin{aligned}
\mathrm{A}^{+} & =\left(y_{1}^{+}, y_{2}^{+}, \ldots, y_{n}^{+}\right) \\
\mathrm{A}^{-} & =\left(y_{1}^{-}, y_{2}^{-}, \ldots, y_{n}^{-}\right)
\end{aligned}
$$

Penjelasan dari persamaan diatas adalah :

$y_{j}^{+}=\left\{\begin{array}{l}\max _{i} y_{i j ; j i k a} j \text { adalah atribut keuntungan } \\ \min _{i} y_{i j ; j i k a} j \text { adalah atribut biaya }\end{array}\right\}$ $y_{j}^{-}=\left\{\begin{array}{l}\min _{i} y_{i j ; j i k a j} \text { adalah atribut keuntungan } \\ \max _{i} y_{i j ; j i k a j} \text { adalah atribut biaya }\end{array}\right\}$

4) Membuat penentuan Jarak nilai Antara masingmasing Calon Karyawan Dengan nilai Matriks Solusi Ideal Positif dan negatif.

Membuat penentuan jarak nilai antara masingmasing Calon karyawan (Ai) dengan matrik solusi ideal yang positif :

$$
D_{i}^{+}=\sqrt{\sum_{\mathrm{j}=1}^{n}\left(y_{i}^{+}-\mathrm{y}_{\mathrm{ij}}\right)^{2}} ; \mathrm{i}=1,2, \ldots, \mathrm{m}
$$

Membuat penentuan jarak nilai antara masingmasing Calon karyawan (Ai) dengan matrik solusi ideal yang negatif :

$$
D_{i}^{-}=\sqrt{\sum_{\mathrm{j}=1}^{n}\left(\mathrm{y}_{\mathrm{ij}}-y_{i}^{-}\right)^{2}} ; \mathrm{i}=1,2, \ldots, \mathrm{m}
$$

5) Membuat perhitungan Nilai Preferensi pada masing-masing kandidat calon karyawan.

Nilai sebuah preferensi (Vi) pada masingmasing Calon Karyawan dirumuskan pada persamaan nomor 8 :

$$
\mathrm{V}_{\mathrm{i}}=\frac{D_{i}^{-}}{D_{i}^{-}+D_{i}^{+}} ; \mathrm{i}=1,2, \ldots, \mathrm{m}
$$

Dari masing-masing niai Vi. Akan dipilih Nilai Vi yang paling besar yang menunjukan bahwa calon karyawa yang mendapatkan niai Vi yang paling besarlah yang dipilih.

\section{HASIL DAN PEMBAHASAN}

\subsection{Pembahasan}

Pada penentuan calon karyawan maka menggunakan data kriteria yaitu Penampilan Fisik, Tinggi Badan, Warna Kulit, Test Psikotest dan Komunikasi. dengan nilai pembobotan sebagai berikut :
Tabel 1. Tabel Kriteria yang digunakan

\begin{tabular}{|l|l|l|l|c|}
\hline \hline $\begin{array}{c}\text { Kode } \\
\text { Kriteria }\end{array}$ & Nama Kriteria & Periode & Attribut & Bobot \\
\hline K01 & Penampilan Fisik & 2019 & benefit & 5 \\
\hline K02 & Tinggi Badan & 2019 & benefit & 5 \\
\hline K03 & Wama Kulit & 2019 & benefit & 5 \\
\hline K04 & Test Psikotest & 2019 & benefit & 5 \\
\hline K05 & Komunikasi & 2019 & benefit & 5 \\
\hline
\end{tabular}

Keterangan mengenai bobot :

5 = penilaian Sangat Baik

$4=$ penilaian Baik

3 = penilaian Cukup

2 = penilaian Buruk

1 = penilaian Sangat Buruk

Seluruh kriteria yang digunakan pada penelitian ini beratribut benefit yang berarti bahwa semakin tinggi nilai dari kriteria maka nilai akan semakin baik.

Berikut ini adalah contoh penilaian dari masing-masing calon karyawan.

1) Setelah masing-masing kandidat calon

\begin{tabular}{|c|c|c|c|c|c|c|}
\hline \multirow[b]{2}{*}{ No } & \multirow{2}{*}{$\begin{array}{l}\text { Nama } \\
\text { Alternatif }\end{array}$} & \multicolumn{5}{|c|}{ Nama Kriteria } \\
\hline & & $\begin{array}{l}\text { Penampilan } \\
\text { Fisik }\end{array}$ & $\begin{array}{l}\text { Tinggi } \\
\text { Badan }\end{array}$ & $\begin{array}{l}\text { Warna } \\
\text { Kulit }\end{array}$ & $\begin{array}{l}\text { Test } \\
\text { Psikotes }\end{array}$ & Komunikasi \\
\hline 1 & $\begin{array}{l}\text { Esliana } \\
\text { Mimity }\end{array}$ & 4 & 5 & 4 & 3 & 5 \\
\hline 2 & $\begin{array}{l}\text { Ilham } \\
\text { Saputra }\end{array}$ & 5 & 5 & 3 & 4 & 4 \\
\hline 3 & Adha Malis & 3 & 4 & 5 & 4 & 3 \\
\hline 4 & Tri Dansyah & 3 & 4 & 5 & 4 & 2 \\
\hline 5 & $\begin{array}{l}\text { Fajar } \\
\text { Oktawirawan }\end{array}$ & 4 & 5 & 3 & 4 & 4 \\
\hline 6 & $\begin{array}{l}\text { Dewi } \\
\text { Wulansari }\end{array}$ & 3 & 4 & 3 & 4 & 5 \\
\hline & Pembagi & 9,16515 & 11,09054 & 9,64365 & 9,43398 & 9,74679 \\
\hline
\end{tabular}
karyawan telah mengikuti serangkain proses seleksi dan mendapatkan penilaian maka ditulis kedalam tabel sebagai berikut

Tabel 2. Tabel Kriteria dengan nilai

2) Membuat penentuan matriks keputusan yang sudah dinormalisasi.

Tabel 3. Tabel Kriteria Ternormalisasi

\begin{tabular}{|l|l|l|l|l|l|l|}
\hline \multirow{2}{*}{ No } & \multirow{2}{*}{$\begin{array}{l}\text { Nama } \\
\text { Altematif }\end{array}$} & $\begin{array}{l}\text { Penampilan } \\
\text { Fisik }\end{array}$ & $\begin{array}{l}\text { Tinggi } \\
\text { Badan }\end{array}$ & $\begin{array}{l}\text { Wama } \\
\text { Kulit }\end{array}$ & $\begin{array}{l}\text { Test } \\
\text { Psikotes }\end{array}$ & Komunikasi \\
\hline 1 & $\begin{array}{l}\text { Esliana } \\
\text { Mimity }\end{array}$ & 0.43644 & 0.45083 & 0.41478 & 0.318 & 0.51299 \\
\hline 2 & $\begin{array}{l}\text { Ilham } \\
\text { Saputra }\end{array}$ & 0.54554 & 0.45083 & 0.31109 & 0.424 & 0.41039 \\
\hline 3 & Adha Malis & 0.32733 & 0.36067 & 0.51848 & 0.424 & 0.30779 \\
\hline 4 & Tri Dansyah & 0.32733 & 0.36067 & 0.51848 & 0.424 & 0.2052 \\
\hline 5 & $\begin{array}{l}\text { Fajar } \\
\text { Oktawirawan }\end{array}$ & 0.43644 & 0.45083 & 0.31109 & 0.424 & 0.41039 \\
\hline 6 & $\begin{array}{l}\text { Dewi } \\
\text { Wulansari }\end{array}$ & 0.32733 & 0.36067 & 0.31109 & 0.424 & 0.51299 \\
\hline
\end{tabular}

3) membuat perhitungan dari matriks keputusan yang sudah dinormalisasi dan diberikan pembobotan. Adapun bobot yang 
dipergunakan dalam penelitian ini adalah $\mathrm{W}$ $=(5,5,5,5,5)$. Sehingga didapatkan hasil sebagai berikut :

Tabel 4. Tabel Kriteria Terbobot

\begin{tabular}{|l|l|l|l|l|l|l|}
\hline \hline \multirow{2}{*}{ No } & \multirow{2}{*}{$\begin{array}{l}\text { Nama } \\
\text { Altematif }\end{array}$} & $\begin{array}{l}\text { Penampilan } \\
\text { Fisik }\end{array}$ & $\begin{array}{l}\text { Tinggi } \\
\text { Badan }\end{array}$ & $\begin{array}{l}\text { Wama } \\
\text { Kulit }\end{array}$ & $\begin{array}{l}\text { Test } \\
\text { Psikotes }\end{array}$ & Komunikasi \\
\hline 1 & $\begin{array}{l}\text { Esliana } \\
\text { Mimity }\end{array}$ & 2.18218 & 2.25417 & 2.0739 & 1.59 & 2.56495 \\
\hline 2 & $\begin{array}{l}\text { Ilham } \\
\text { Saputra }\end{array}$ & 2.72772 & 2.25417 & 1.55543 & 2.12 & 2.05196 \\
\hline 3 & Adha Malis & 1.63663 & 1.80334 & 2.59238 & 2.12 & 1.53897 \\
\hline 4 & Tri Dansyah & 1.63663 & 1.80334 & 2.59238 & 2.12 & 1.02598 \\
\hline 5 & $\begin{array}{l}\text { Fajar } \\
\text { Oktawirawan }\end{array}$ & 2.18218 & 2.25417 & 1.55543 & 2.12 & 2.05196 \\
\hline 6 & $\begin{array}{l}\text { Dewi } \\
\text { Wulansari }\end{array}$ & 1.63663 & 1.80334 & 1.55543 & 2.12 & 2.56495 \\
\hline \hline
\end{tabular}

4) Menghitung nilai dari matriks solusi ideal positif dan negatif.

Tabel 5. Tabel Solusi Ideal Positif dan Negatif

\begin{tabular}{|l|l|l|l|l|l|}
\hline \hline $\mathrm{A}+$ & 2.72772 & 2.25417 & 2.59238 & 2.12 & 2.56495 \\
\hline $\mathrm{A}-$ & 1.63663 & 1.80334 & 1.55543 & 1.59 & 1.02598 \\
\hline \hline
\end{tabular}

5) Menghitung nilai jarak antara masingmasing Calon Karyawan dengan nilai dari matriks solusi ideal positif dan negatif.

Tabel 6. Tabel Nilai Jarak

\begin{tabular}{|l|l|}
\hline \hline $\mathrm{D}+$ & $\mathrm{D}-$ \\
\hline 0.92051 & 1.77147 \\
\hline 1.1569 & 1.65144 \\
\hline 1.27908 & 1.3544 \\
\hline 1.5713 & 1.62767 \\
\hline 1.27908 & 1.3544 \\
\hline 1.5713 & 1.62767 \\
\hline
\end{tabular}

6) Menghitung sebuah nilai dari preferensi untuk masing-masing Calon Karyawan

Tabel 7. Tabel Nilai Preferensi

\begin{tabular}{|l|l|l|}
\hline \hline No & Nama Altematif & \multicolumn{1}{|c|}{$\begin{array}{c}\text { Nilai Alternatif } \\
\text { (V) }\end{array}$} \\
\hline 1 & Esliana Mimity & 0.65806 \\
\hline 2 & Itham Saputra & 0.58805 \\
\hline 3 & Adha Malis & 0.44861 \\
\hline 4 & Tri Dansyah & 0.37516 \\
\hline 5 & Fajar Oktawirawan & 0.5143 \\
\hline 6 & Dewi Wulansari & 0.50881 \\
\hline \hline
\end{tabular}

Dari perolehan hasil akhir perhitungan menggunakan algoritme TOPSIS maka didapatkan nilai tertinggi atas nama Alternatif Esliana Mimity yaitu dengan perolehan nilai akhir sebesar 0.659 Sehingga Alternatif yang dipilih menjadi Karyawan yaitu Esliana Mimity.

\subsection{Bentuk dari tampilan program}

a. Menu Utama aplikasi

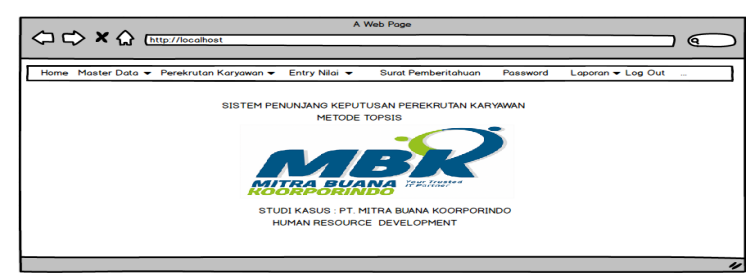

Gambar 3. Tampilan Menu utama

Pada bentuk tampilan Menu utama program terdapat beberapa fungsi yaitu Master data yang berfungsi untuk mengentry divisi, rekanan dan kriteria, dan menu perekrutan karyawan yang berguna untuk pengentryan perekrutan dan entry nilai yang berguna untuk memasukan nilai dari masing-masing karyawan, surat pemberitahuan yang berguna untuk menginformasikan kepada calon karyawan yang telah diterima sampai dengan menu laporan yang berguna untuk melaporkan data mengenai calon karyawan yang terpilih.

b. Proses Perhitungan menggunakan Algoritme TOPSIS

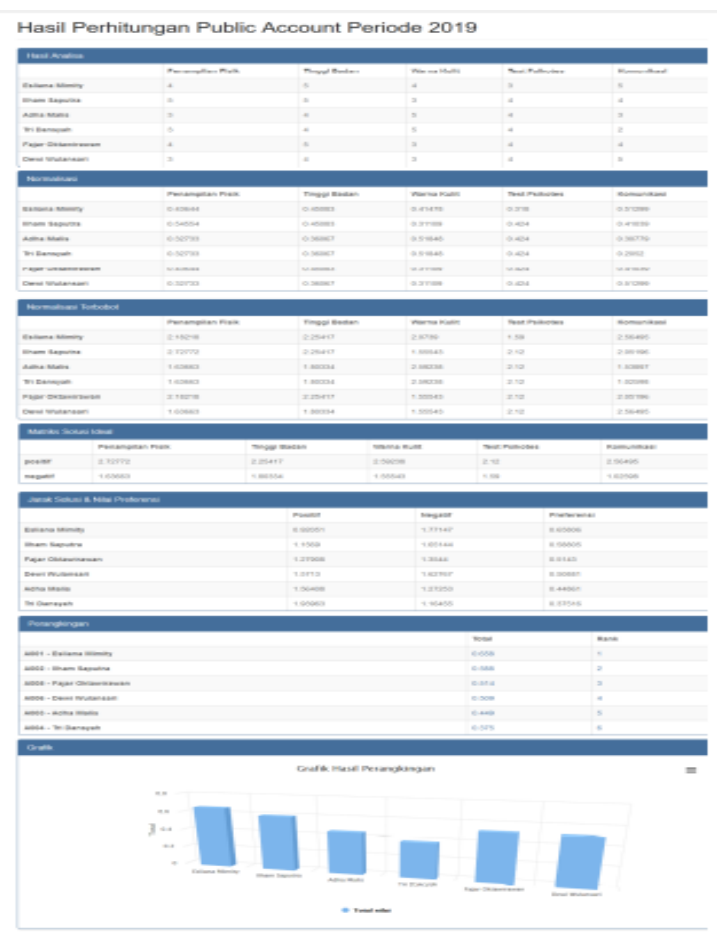

Gambar 4. Proses Perhitungan

\section{KESIMPULAN}

Kesimpulan yang dapat diambil dari permasalahan pada penelitian ini adalah sebagai berikut :

a. Staf HR \& GA dalam mengolah data menjadi lebih cepat, efektif dan efesien. 
b. Dengan adanya sistem penunjang keputusan maka perhitungan sudah menggunakan algortime sehingga kesalahan dalam perhitungan tidak terjadi kembali.

c. HR \& GA Dept. Head lebih mudah memilah antar pelamar satu dengan lainnya sesuai kebutuhan divisi, karena terbantu dengan sistem

d. HR \& GA Dept. Head mampu membuat keputusan mengenai calon karyawan yang akan dipilih berdasarkan bentuk keluaran aplikasi yang berupa perangkingan dari masing-masing kandidat calon karyawan.

Untuk pembuatan aplikasi kedepannya maka disarankan yaitu :

a. Penelitian kedepannya bisa memadukan beberapa algoritme sistem penunjang keputusan lainnya seperti Profile Matching, Weigted Product, AHP dan lain sebagainya.

b. Kriteria yang digunakan bisa ditambahkan sesuai dengan kebutuhan dari masingmasing tempat penelitian

\section{DAFTAR PUSTAKA}

[1] Mega Octa Setyawatie dan Amat Suroso. Jurnal Teknologi Terpadu Vol. 2 No. 1. Juli 2016. ISSN 2477-0043.

[2] Lie Jasa dan I Nyoman Mahayasa Adiputra. 18-19 Maret 2019. Sistem Penunjang Keputusan Perekrutan Pegawai Menggunakan Perangkingan Madm Topsis dan Klasifikasi Naïve Bayes. Seminar Nasional Teknologi Informasi dan Komunikasi 2016 (SENTIKA 2016) ISSN: 2089-9815. Yogyakarta.

[3] Siagian Yessica. Juni 2018. Seleksi Penerimaan Karyawan Baru Menggunakan Metode Topsis, Jurnal Mantik Penusa, Vol 2, No 1, ISSN 2580-9741.

[4] Aliy Hafiz, Muhammad Ma'mur, Sistem Pendukung Keputusan Pemilihan Karyawan Terbaik Dengan Pendekatan TOPSIS (Studi Kasus: PT. Telkom Cab. Lampung). Jurnal Cendikia Vol. XV | Cendikia 2018, ISSN:0216-9436.

[5] Hilyah Magdalena, 2012, Jurnal Sistem Pendukug Keputusan, 10 Maret 2012.

[6] Nur Aini dan Fahrul Agus, 2017. Penerapan Metode TOPSIS Dan Analytic Hierarchy Process Untuk Pemilihan Koperasi Berprestasi, Jurnal Infotel 9(2).

[7] Turban, Decision Support System and Intelligent System. 9th ed. 2010. 